\title{
BUILDING RELATIONSHIPS BETWEEN ENGINEERING AND THE Trades THROUGH SERVICE LEARNING
}

\author{
Darlene Spracklin-Reid, Amanda Ryan and April Smith \\ Memorial University \\ darlenesr@mun.ca,amr078@mun.ca, a.smith@mun.ca
}

\begin{abstract}
Engineers and tradespeople have a long history of working together in a variety of industries. At Memorial University, we are building that relationship through service learning. In partnership with Together by Design, engineering students have the opportunity to work on community service projects with students, apprentices and journey persons from a variety of trades. Engineering students are able to learn from their fellow team members, as well as share some of their own areas of expertise and skill. Through this collective learning process, relationships are established along with a mutual understanding of the value of teamwork.
\end{abstract}

Keywords: Service-Learning, Experiential Learning, Teamwork, Community Service

\section{INTRODUCTION}

Service-learning is a pedagogical strategy that sees learning and service objectives combined to the mutual benefit of both the student and the community. Servicelearning can also be described as volunteerism, community-based learning, experiential education, etc. No matter how it is described, service-learning is fundamentally based on offering meaningful service to the community while engaged in active learning [5].

Service-learning can be informal, or it can be formally integrated into the curriculum [4]. In either case, the goal is for students to connect what they have learned in the classroom to the impact this learning can have on the community at large. Service-learning grows responsible citizens who understand that through their professions, they can contribute to their communities in meaningful ways. Service learning activities have the potential to effect positive change on a personal and societal level [4]. In addition, Service-learning has positive impacts on individual student learning. It has been shown to have a positive impact on academic learning and student grades [8].

By being part of an interdisciplinary team, students are learning to work together, take on leadership roles, learn new skills and develop respect for other trades and professions. Interdisciplinary teams have many benefits for students. It builds respect for other fields of endeavor, and it deepens the understanding students have for their own area study, requiring them to think through their own area of expertise as they share their knowledge and teach others [2]. It requires that students think about the project from another point of view. Trust and respect are foundational to true interdisciplinary collaboration and research shows that collaborating with non-engineers builds trust in other experts [2].

Working as a team requires students to interact with others under continuously changing circumstances. It requires them to be responsive to a dynamic situation where teaching and learning are happening simultaneously. Skills can often be best acquired in a group setting, with experiential activities that allow for each individual to participate, give and receive feedback, and observe others learning the same skill [10].

\section{RECONSTRUCTION AND RECOVERY: AN INTERDISCIPLINARY SERVICE-LEARNING PROJECT}

\subsection{Together by Design}

Motivated by a desire to help the people of New Orleans recover from the devastating effects of Hurricane Katrina and to provide service-learning opportunities for students, Together by Design (TBD) was established in 2007. The organization was founded to develop interdisciplinary service-learning projects for postsecondary students studying in Newfoundland and Labrador. Since its inception, TBD has been working to rebuild the neighbourhood of Broadmoor, New Orleans. $100 \%$ of all properties in Broadmoor suffered between approximately 6 and 10 feet of flooding following the hurricane [12].

TBD has brought together teams of student volunteers from the following programs:

- civil engineering,

- civil engineering technology,

- architectural engineering technology,

- geomatics engineering technology, 
- $\quad$ construction/industrial electrician,

- plumbing,

- carpentry,

- journalism.

Students from these programs have engaged in crossdisciplinary service-learning projects in the neighbourhood. They apply their academic knowledge and skills whilst learning from each other. 2013 and 2104 TBD student volunteers are drawn from post-secondary institutions in Newfoundland and Labrador including Memorial University, Local UA 740 Plumbers and Pipefitters Training School and the Carpentry Millwright College. Students are studying civil engineering, plumbing and carpentry and are accompanied by mentors who are fully qualified journeypersons and a professional engineer.

\subsection{Project History}

Even though Hurricane Katrina struck New Orleans back in 2005, and the neighbourhood has made significant strides toward recovery, much work remains to be done. Broadmoor is working to improve their Educational Corridor, (see Figure 1), an area in the heart of the neighbourhood that includes the Andrew Wilson Charter School, the Rosa Keller Library, a community center, churches and playgrounds. Through redeveloping the Educational Corridor and its services that families require, Broadmoor is attracting residents back to the neighbourhood and it serves as a model of recovery to other New Orleans neighbourhoods. [1].

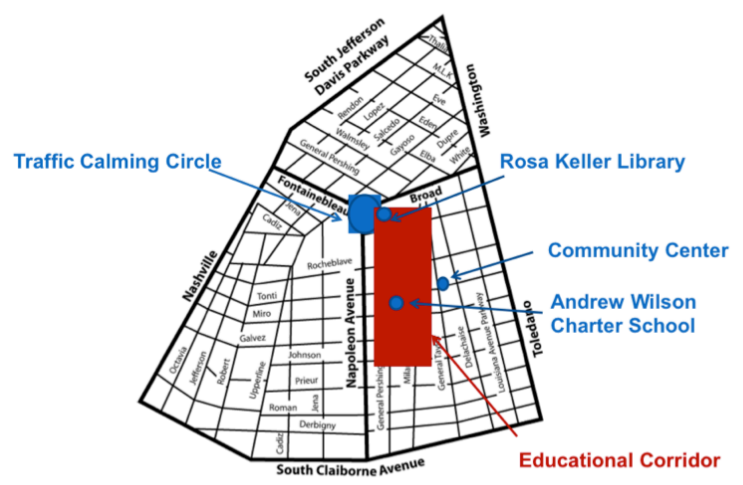

Fig. 1. Map of Broadmoor

From 2007 to 2012, students and their mentors from Newfoundland and Labrador worked on various projects for the Broadmoor neighbourhood ranging from design work to construction projects. Some of these projects include:
- Designing a roundabout to slow traffic around the library and improve safety for pedestrians.

- Improving green space around the Andrew Wilson Charter School so that neighbourhood children would have an inviting and safe place to play.

- $\quad$ Rebuilding numerous sidewalks and wheelchair ramps.

- Repairing the community center.

- Completing residential construction projects, including carpentry, plumbing and electrical work.

- Constructing a structural foundation and fire escape for the neighbourhood preschool.

- Repairing foundations.

- Constructing benches, fences and making playground improvements throughout the neighbourhood.

As evidenced by these projects, the TBD interdisciplinary student team is able to contribute to the rebuilding of New Orleans in a very tangible way. They are able to apply their theoretical studies to hands-on, practical work that leaves real benefits in Broadmoor and a sense of accomplishment in the students.

For students from Newfoundland and Labrador, this international service-learning experience has profound impacts. The process of creating global citizens can benefit from service-learning pedagogy by exploring the concrete implications of theoretical concepts in local as well as transnational contexts [6]. In addition to the concrete impact that these projects have had in Broadmoor, the service-learning work in New Orleans has had lasting impacts upon our students and in the communities they call home. The student volunteers come from all parts of the province and upon returning to Newfoundland and Labrador, they have continued to volunteer in their communities. They are serving as municipal councilors, volunteer firefighters and search and rescue workers. They are redesigning school parking lots to improve safety and accessibility. They are working with their communities to design playgrounds and recreational facilities. They are working with elementary schools to construct wheelchair ramps [13]. 


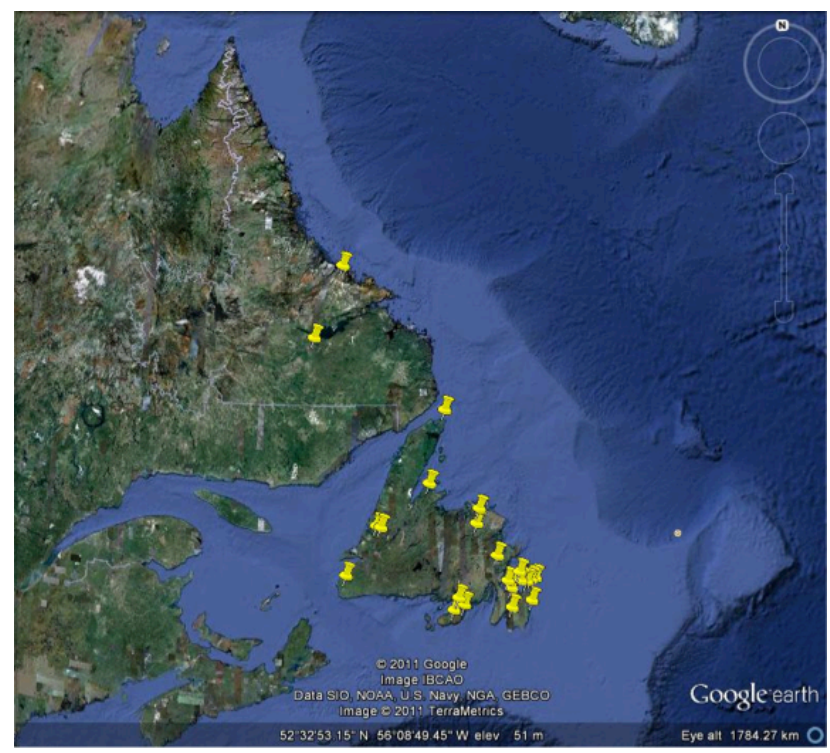

Fig. 2. Hometowns of TBD Students Team Members, 2008-2013)

\subsection{Reconstruction and Recovery: New Orleans 2013 Projects}

The TBD Reconstruction and Recovery: New Orleans 2013 team traveled to New Orleans from October $26^{\text {th }}-$ November $11^{\text {th }}, 2013$. The team stayed at a hostel, sharing accommodations and working together on construction projects for a two-week period. The team was comprised of:

- two civil engineering students,

- two plumbing students,

- four carpentry students,

- one journeyperson plumber,

- one journeyperson carpenter,

- one professional engineer.

The neighbourhood of Broadmoor has come a long way since Hurricane Katrina and the flooding that followed. The neighbourhood's residential reconstruction rate has reached $87 \%[1]$, however there is still work to be done. In particular, Broadmoor is working to ensure that the neighbourhood's redevelopment is sustainable, and the community is even better than it was before the flooding[1]. Broadmoor is also reaching out to surrounding neighbourhoods to share their model of recovery. TBD is working with Broadmoor as it reaches out and in 2013, the inter-disciplinary team completed projects in and around the neighbourhood, as well as in the Upper Ninth Ward, Center City and St. Bernard Parish [13].
Reconstruction and Recovery: New Orleans 2013 projects included:

- reconstruction of sidewalks,

- reconstruction of a concrete entrance at the Church of the Annunciation,

- residential reconstruction projects, including plumbing, drywall, plastering and general carpentry,

- plumbing and ventilation repairs at a neighbourhood church and preschool [13].

\subsection{Project Impacts}

Living and working together as an interdisciplinary service-learning team allowed students to learn from each other, learn more about their own disciplines and provide meaningful service. Service-learning can be a bridge between engineering and the trades. In fact, service learning can be a teaching tool that enables students to recognize the interrelated aspects of all learning and life experiences [7]. The engineering students that participated in Reconstruction and Recovery: New Orleans 2013 noted that they learned a great deal from the trades students, and they were able to gain a deeper understanding of their own skills as they taught other team members.

"When I was first picked for the team, I felt a combination of emotions - excitement packed with a lot of nerves. I couldn't wait for the opportunity to travel to an amazing place like New Orleans and do my small part in helping to restore the city. As the date came closer to leave, I questioned whether I would be able to help at all. I had no hands-on experience using tools and no idea how to fix or build anything. Within the very first day of arriving in New Orleans and meeting the team, I realized how skilled the tradespeople on the team were, and more importantly, how willing they were to teach their trade. Before I knew it, I was using a jackhammer, climbing up on scaffolds and cutting rebar. The small scope of work that I helped with, gave me so much respect for my fellow teammates and the time they put into their profession." - Amanda Ryan, Term 5 Civil Engineering Student, Memorial University

"One of the most valuable things I learned while working with the other team members is the value a person with field experience can have on any project. Sometimes, what our books may tell us is the best solution to a problem can often be much more complicated to implement than necessary, and merely asking someone who has worked in this area for a while can simplify things drastically. Even simply knowing the importance of their expertise and 
respecting that can create a much more productive work environment. The hands-on skills that were taught to me by my teammates, and now friends, were also invaluable. I enjoy independence and a hands-on approach, which I can now enjoy even more as a result of their assistance and teaching." - April Smith, Term 5 Civil Engineering Student, Memorial University

Service-learning also has an impact on self-efficacy. As students apply their skills in a meaningful way, they begin to feel more confident about their abilities to contribute to their professions and their communities. Service learning enhances students' self-concepts by allowing them to make an impact through active and meaningful contributions to communities [7]. A team that draws on students from a variety of programs enhances this increase in self-efficacy. Working together, students realize what they are able to accomplish and the goals they can achieve. Research shows that self-efficacy is increased in cross-disciplinary teams working on servicelearning projects [9].

"My time in New Orleans not only provided me with the chance to learn, but also the chance to apply and teach. I had never realized how much I learned in my studies until I saw how it was applied in a hands-on situation. Service-learning provided me with tangible experience to go along with the lectures I'd listened to and the books I'd read. As well, I got to pass on some of my knowledge to other teammates. Through school, I had become familiar with surveying equipment and in New Orleans, I was able to show one of the plumbing students how to level. This alone solidified in my mind that I added value to the team and could really help in the reconstruction effort." - Amanda Ryan, Term 5 Civil Engineering Student, Memorial University

\footnotetext{
"Being able to apply some aspects of our schooling to a tangible real life situation is very satisfying. Not only can we look at the problem and help come up with a solution, we also get to help implement it and see it all come together. This is why service-learning can have such a huge impact, and is so rewarding and satisfying. It allows you to use your skills, along with your teammates'skills, to solve problems and complete projects from start to finish. This can be much more satisfying and liberating than merely being involved in the design portion, etc. I believe the experience and opportunity to volunteer that service-learning provides is invaluable to a professional engineer's growth, or even growth as a person." - April Smith, Term 5 Civil Engineering Student,
}

\section{CONCLUSION}

Rarely do we read complaints about the technical performance of engineering students. However, the lack of people skills among scientists, engineers, computer specialists, and other problem solvers is notorious [10]. The Canadian Engineering Accreditation Board (CEAB) has recognized the need for students to receive a wellrounded education so that they are prepared to become responsible professionals. The $\mathrm{CEAB}$ has established accreditation requirements for engineering graduates to possess series attributes. These attributes include technical knowledge and problem solving skills, but they go on to address the fundamentals of professionalism. They require students to have:

- An ability to work as an effective team member, preferably in a multi-disciplinary setting.

- An understanding of the roles and responsibilities of the professional engineer in society.

- An ability to analyze social and environmental aspects of engineering activities. Such ability includes an understanding of the complex interactions that engineering has with the economic, social, health, safety, legal, and cultural aspects of society.

- An ability to apply professional ethics, accountability, and equity [3].

In working with Together By Design, engineering students were part of a team of volunteers that included students and mentors from both engineering and the trades. With a team that included plumbing, carpentry and engineering students, they learned to work in a multidisciplinary team, preparing them for real world working situations, gaining more understanding of the trades in the process. They learned about the benefits of volunteerism and the social and economic impacts of engineering. They acted as both leaders and team members as they alternated roles and responsibilities. This experience in interdisciplinary service-learning contributed to their development of the CEAB graduate attributes for engineers.

\section{References}

[1] Broadmoorcorp.com, Broadmoor Development Corporation, Available as of April 08, 2014 from http://broadmoorcorp.com/about/

[2] Maura Borrego and Lynita Newsander , "Characteristics of successful cross-disciplinary engineering education collaborations.," Journal of Engineering Education, vol. 97, no. 2, pp. 123-134, 2008. 
[3] Engineers Canada, Canadian Engineering Accreditation Board, "2010 Accreditation Criteria and Procedures", www.engineerscanada.ca, 2010.

[4] Millicent Kelly, "Beyond classroom borders: Incorporating collaborative service learning for the adult student," Adult Learning, vol. 24, no. 2, pp. 82-84, 2012.

[5] Betty McDonald, “Assessment in Service Learning," Online Submission. October 2012 [cited April 9, 2014]; Available from: ERIC.

[6] Nuria Alonso García and Nicholas V. Longo, "Going global: Re-framing service-learning in an interconnected world," Journal of Higher Education Outreach and Engagement, vol. 17, no. 2, pp. 111-135, 2013.

[7] Mary Prentice and Rudy Garcia, "Service learning: The next generation in education," Community college Journal of Research and Practice, vol. 24, no. 1, pp. 19-26, 2000.

[8] D. Rama, S, Ravencroft, S. Wolcott and E. Zlotkowski, "Service-learning outcomes: guidelines for eductors and researchers," Issues in Accounting Education, vol. 15, no. 4, pp. 657-692, November, 2000.
[9] Scott Schaffer, Xiaojun Chen, Xiumei Zhu, and William Oakes, "Self-efficacy for cross-disciplinary learning in project-based teams," Journal of Engineering Education, vol. 101, no. 1, pp. 82-94, 2012.

[10] Elaine Seat and Susan Lord, "Enabling effective engineering teams: A program for teaching interaction skills," Journal of Engineering Education, vol. 88, no. 4, pp. 385-390, 1999.

[11] G. Skates, "Interdisciplinary project working in engineering education," European Journal of Engineering Education, vol. 28, no. 2, pp. 187-201, 2010.

[12] S. Stack, Repetitive loss analysis \#3: City of New Orleans, Broadmoor Neighborhood. New Orleans, LA: University of New Orleans Center for Hazards Assessment, 2006, 31 pp. Available as of April 08, 2014 from http://floodhelp.uno.edu/uploads/images/In\%20the\%20New s/BroadmoorFinalReport.pdf

[13] togetherbydesign.ca, Together by Design, Available as of April 08, 2014 from http://togetherbydesign.ca/about/ 